\title{
Legal Use of Archives in Romania after 1989: Impact and Effects on the Institution of National Archives
}

\author{
ANA-FELICIA DIACONU, PH.D.
}

lecturer Facultatea de Arhivistică (Faculty of Archival Science), Academia de Poliție "Alexandru Ioan Cuza”, Aleea Privighetorilor, nr. 1-3, Sector 1, Bucharest, Romania e-mail: felicia.diaconu@gmail.com

Legal Use of Archives in Romania after 1989: Impact and Effects on the Institution of National Archives

\section{ABSTRACT}

The paper covers the way in which the institution of the National Archives was confronted with and tackled citizens' necessities to prove or redeem their rights after the change of the political regime in 1989. A first direction envisages the land legislation, which had a major impact on the National Archives`activity. A second direction is based on the National Archives ' control duties upon archives creators and owners institutions by inspecting the way in which they issue documents attesting the rights of citizens. All these developments have made the National Archives a very active institution with a major role in terms of proof of the claimed rights by citizens.

Key words: use of archives, Romania, legal value, post-communist regime

Uso legale degli archivi in Romania dopo il 1989: impatto ed effetti sull'istituzione dell'Archivio nazionale

SINTESI

L'articolo tratta del modo in cui l'istituzione dell'Archivio nazionale si è posto ed ha corrisposto alle aspettative dei cittadini allo scopo di provare o riscattare i propri diritti dopo il cambio di regime politico nel 1989. Una prima direzione prefigura la legislazione locale che ha avuto maggiore impatto sull'attività dell'Archivio nazionale, una seconda direzione è basata sui compiti di controllo dell'Archivio nazionale sulle istituzioni produttrici e detentrici di archivi esaminando il modo in cui esse emettono documenti attestanti i diritti dei cittadini. Tutti questi sviluppi hanno reso l'Archivio nazionale un'istituzione molto attiva con un grande ruolo in termini di prova dei diritti reclamati dai cittadini.

Parole chiave: uso degli archivi, Romania, valore legale, governo post-comunista

Uporaba arhivskega gradiva za upravne namene v Romuniji po letu 1989: vpliv in učinki na Nacionalni arhiv

\section{IZVLEČEK}

Avtorica v prispevku predstavlja načine, $s$ katerim se je Nacionalni arhiv po spremembi političnega režima leta 1989, soočil s potrebami uporabnikov, da izkažejo ali uveljavijo svoje pravice. Najprej predstavlja zakonodajo o zemljiščih, ki je imel velik vpliv na dejavnost Nacionalnega arhiva, temu pa sledi predstavitev kontrolnih nalog Nacionalnega arhiva, ki nadzira izdajanje dokumentacije, ki potrjuje pravice državljanov, s strani ustvarjalcev in imetnikov. Vse to je spremenilo Nacionalni arhiv v zelo dejavno institucijo na področju zagotavljanja pravic državljanov.

Ključne besede: uporaba arhivskega gradiva, Romunija, pravna veljava, post-komunistični režim

Folosirea documentelor de arhivă în scopuri juridice în România după 1989. Impactul şi consecințele asupra instituției Arhivelor Naționale

REZUMAT

Lucrarea tratează modul în care instituția Arhivelor Naționale s-a confruntat și a răspuns necesităților cetățenilor 
de a-și proba sau reconstitui drepturile, după schimbarea regimului politic, în 1989. O primă direcție are în vedere legislația funciară care a avut un impact major asupra activității Arhivelor Naționale. $\mathrm{O}$ a doua direcție pornește de la atribuția de control a Arhivelor Naționale la instituțiile creatoare și deținătoare de documente, în sensul verificării modului în care acestea eliberează cetățenilor documente care le atestă drepturile. Toate aceste evoluții au făcut din Arhivele Naționale o instituție foarte activă și cu un rol major din perspectiva probării drepturilor revendicate de cetateni.

Cuvinte cheie: folosirea arhivelor, România, valoare juridică, regimul post-comunist

The political and socio-economic development in post-revolutionary Romania assumed multiple transformations in Romanian society, upheavals caused primarily by the transition from a centralized, communist state towards a democratic regim. The difficulties of such a process have been and continue to be enduring and with implications in all registers of public life manifestations, as the domestic institutional system had to be radically transformed. The archives domain could not remain immune to such a performance, the representative institution in this regard, i.e. the National Archives, had to be connected to the overall progress of society.

The paper covers the way in which the institution of the National Archives was confronted with and tackled citizens' necessities to prove or redeem their rights after the political regime changed in 1989. This reality illustrated in a more than eloquent manner the legal and evidential value of documents, whether they are currently stored at the National Archives or at the creators. Thus, even today, the most requested documents from the National Archives concerning citizens' rights are, according to the activity report for 2015 of the institution $(N A R, 2015)$, as follows:

- Certificates of years in service used to calculate / recalculate pensions;

- Deed of conveyance, donations, wills, contracts, inheritance, court orders/rulings;

- Registers` excerpts drawn at censuses in 1930, 1941, 1948;

- Excerpts from tables with appropriated or expropriated land people based on the land reforms from 1864, 1921, 1945;

- Copies from the State Council Decrees ${ }^{1}$ and Presidential Decrees

- Wealth declarations and statements, settlement dossiers for refugees from Cadrilater (Quadrilateral);

- Statements of refugees from Northern Transylvania, deportations to Transnistria, German population sent to the USSR.

The categories of documents listed above also show, simultaneously, the causes that led to the growth of requests for genuine, authentic records according to the original documents kept at the National Archives. The first one refers to:

\section{Liquidation of the great state property during the communist regime and the founding conditions for a market economy}

A characteristic feature of the communist system was the confiscation/forfeiture of private property, evidenced both by taking over farmland and their inclusion within the specific land structures of the regim, and by seizuring the buildings that belonged to the so-called kulaks. The process began with the nationalization $\operatorname{law}^{2}(L a w, 1948)$ in 1948 and it was based on abusive measures. On 2nd March 1949, the collectivization started intesively (Decree, 1949), and until 1962 almost all private agricultural properties in the country had been confiscated and merged into staterun agricultural enterprises (for an overview see Iordachi \& Dobrincu, 2009). It then followed buildings and homes. In 1950 (Decree, 1950), former buildings of manufacturers, landowners,

1. The State Council was established in March 1961 and operated until 1989. This governing body has held the functions and duties of a head of state of the Romanian People's Republic and the Socialist Republic of Romania. Its membership has varied over time, the Chairman of the Council holding since 1974 the status of president of the Republic, following the amendment of the Constitution.

2. Under the law, 1,050 private enterprises in industry, banking or insurance went into state`s ownership, as a consumer good of the people, the action being presented as one for the good of the people and in its name. 
bankers, and merchants, hotels with their entire inventory, buildings under construction, damaged or destroyed, became state property as chattels of the entire people, without any compensation.

Most of the former communist countries have addressed the issue of property restitution in a decisive manner immediately after 1990. Thus, in Albania, Bulgaria, Hungary, the Czech Republic and in the former East Germany, restitution of nationalized properties laws were adopted before the end of 1993, in Croatia in 1996, and in Macedonia in 1998 (TVR, 2013). The restitution of property abusively taken over by the state is the ordinary means by which a political community atones for and takes responsibility for its past misdeeds. "An intrinsic component of the rule of law that East European countries wish to adhere to, property restitution is one of the ritual performances that could bring about public vindication and maintain the legitimacy of the new democracies by establishing moral principle though the identification of wrongdoing and the righting of wrong" (Borneman, 1997, cited in Stan, 2006, p. 182).

In Romania, the process of restitution of property confiscated during the previous regime and the restoration of property rights began in 1991 with the entry into force of the Land Law (Law, 1991) and its implementing regulation ${ }^{3}$. Under the provisions of article 11 of the above-mentioned law, the establishment of ownership was made on the basis of a situation of the land owned by the common agricultural production on 1 January 1990, registered into the accounting system of the general cadastre or agricultural register.

The identification of properties to be refunded or for which compensations had to be provided could not have been achieved other than on the basis of documents. The analysis of the identifying process of the necessary information for such an approach indicates a complex activity onto which the historical evolution of each province played its role.

Thus, it is well known that national territories which were in the past parts of the Austro-Hungarian Empire benefited from the early introduction of a centralized system of registration of real estate, with continuity nowadays. On the other hand, we have, by strictly referring to Romania, example of dissipation of information of this kind.

Reporting this reality to the process of reconstituting the patrimonial rights of each person who requested this shows us the challenge to which the „document" and the institution, which manages it, had to respond. From this point of view, the reality was grouped in two directions: one simplistic/reductionist based on the use of a synthetic document category, containing relevant information, and another broken and therefore, more difficult, which involved identifying any information that could serve the purpose stated above. tary basis:

Depending on the geographical area, reinstatement of property right had a different documen-

In Transylvania, Banat and Bucovina, former Austrian provinces which used the land book system ${ }^{4}$ from the end of the 19th century (see Badea, Badea, 2015), it represented the main source of documentation and auxiliary to it other types of documentation such as agricultural registers, and censuses from 1941 and 1948.

\footnotetext{
3. According to him archives of the former Common Agricultural Policy had to be taken by the municipalities to which they were assigned from a territory aspect, which led in many cases to the dispersal and, ultimately, to the destruction of many archives of this type due to the fact that the staff of the National Archives was insufficient to supervise the way in which the transfer was made. (Porumbăcean, s.a.).

4. In these regions, some specific work started by the Austrian since 1794 and had bee continued after 1850 as "Concretual Cadastre", consisting of delineation, description and representation of communities borders, sector boundaries, river networks and roads network. The Emperor Francis II was the one who introduced modern cadastre, but during the administration of Austro-Hungarian Empire after 1867, under Emperor Franz Joseph I, also strengthened land book system.
} 


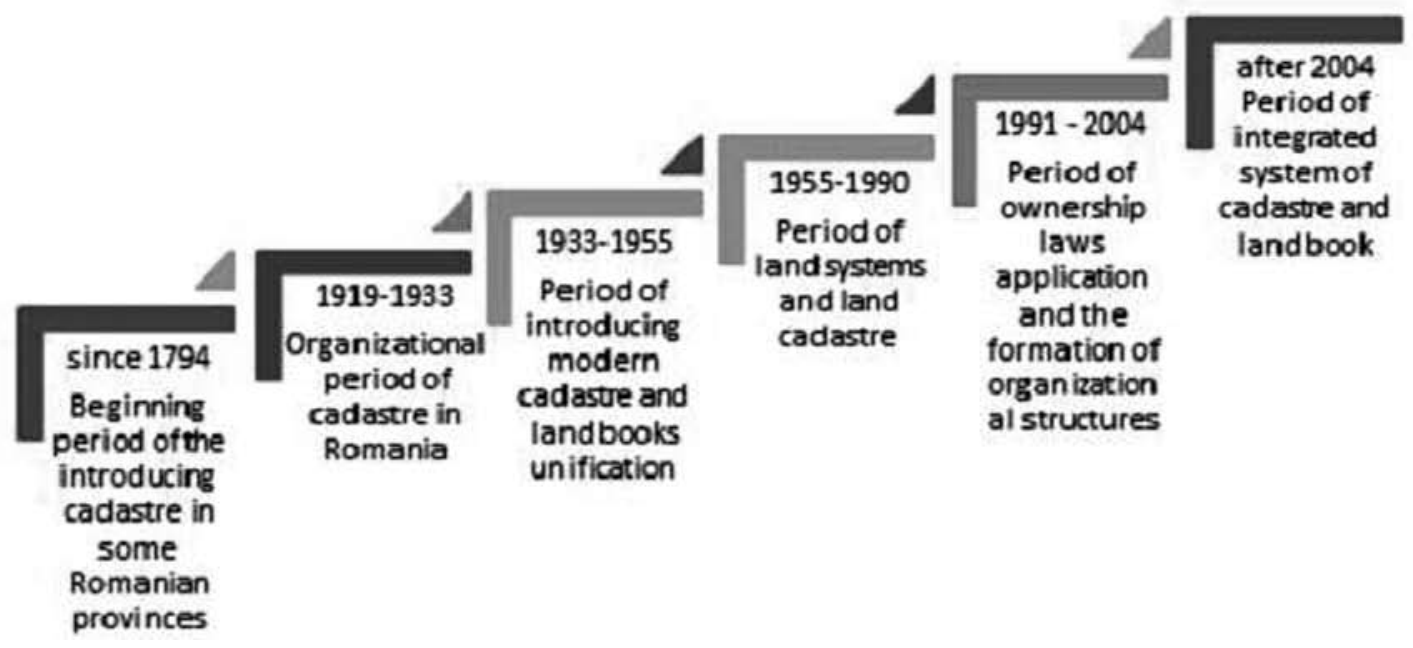

Image 1: Main Periods of Cadastral Changes in Romania (Badea, Badea, 2015, p. 3/14)

In the former Kingdom the restoration of property rights has been much more difficult and it relied on any information identified in the archives: The People's Council decisions under which different land and/or property was taken by the state, documents on expropriation of properties of personons belonging to "kulaks people" established under Law no. 187/1945 (estates larger than 50 ha) and under Decree no. 83/1949 (50 ha estates and mansions) the status of properties declared in the 1948 Census (they provide the only information on forest lands); Deeds of conveyance, wills, deeds of donation concluded at notary/judiciary courts; civil or criminal judgments issued by notary/judiciary courts; expropriation decrees, accompanied by annex lists issued by the Presidium of the Grand National Assembly and the State Council, documentary evidence of payment of tax for different properties (tax transcripts).

From an archival perspective, these realities revealed the fluctuating nature in terms of quality of evidence of the same kind of information/document.

\section{Establishing the compensatory legislation for the Romanian population who had to abandon their goods and properties in the context of Romania's territorial losses during the Second World War}

In 1940, Romania lost territory in both east and west: in June 1940, after receiving an ultimatum from the Soviet Union, Romania ceded Bessarabia and Northern Bukovina, in August 1940, Northern Transylvania was awarded to Hungary by Germany and Italy through the Second Vienna Award and Southern Dobruja (Cadrilater, en. Quadrilateral) was also lost to Bulgaria. The Romanian population from these territories was forced to take refuge in Romania or to be deported into the Russian territories, losing the property and assets owned. After 1989 the questions of rewarding, even if only partially, of the losses of this category of the population had been risen.

Unjust deprivations suffered by Romanian citizens in the context of the Second World War determined the Romanian state that, after the restoration of democracy, to take compensatory measures for those who, for reasons beyond their control, had to bear them.

The political and historical context has put its hall-mark in this event as well. Although the compensatory principle contained in the passed legislation addresses to all the Romanians from the former provinces which until 1940 or 1944 belonged to Romania, who suffered privation from political reasons, its applicability was searing different. Causes derive, largely, from the specific international political context. 
Thus, the Romanians who have abandoned their goods in Cadrilater tranferred to Bulgaria, the recomposition of the rights the entitled persons could benefit from was made relatively easy given that, through the Treaty signed on 7 September 1940 in Craiova, the population exchange between the two signatories states was achieved, and the Romanian state came into possession of a good part of documents created by institutions that have worked in this territory between 1912 and $1940^{5}$.

According to Article 1 of Law no. 9/19986 (Law, 1998) harmed Romanian citizens following the application of the Treaty between Romania and Bulgaria, signed at Craiova on 7 September 1940 benefited from compensation, in so far as not previously received or only partially received compensation for the immovable property - buildings and land - for unpicked crops and as well for orchards they had owned in the counties Durostor and Kaliakra, transferred to Bulgaria. By the above-mentioned provisions benefited also Romanian citizens, legal heirs of former owners, as well as Romanian citizens injured following optional or mandatory immigration from other counties of Bulgaria than the counties tranferred to Bulgaria, Durostor and Kaliakra.

Extremely useful in this context have proven to be the records kept in the National Archives on the properties owned by refugees in Cadrilater in 1940, documents necessary for obtaining the compensations.

In the case of Bessarabia and Northern Bukovina the circumstances were different, as withdrawal from these provinces was done urgently, and the end of World War brought for Romania the occupation by Soviet troops, as well as releasing to Russia archives created by the Romanian state institutions that functioned in these territories during the interwar period (See Tineghe, 2012). Necessary documents proving refugee status in these areas are few and make it difficult to implement the applicable compensatory legislation (Law, 2003).

\section{Granting specific rights to social securities}

The transition from communist economy to a capitalist type of economy did not have a positive effect on archives created by former enterprises and companies. Most laws issued in 1990-2000, starting with Law no. 15 on the reorganization of state economic units as autonomous and commercial companies, the Law on privatization of commerical societies no. 58/1991, Law no. 64/1995 on reorganization and judiciary liquidation etc. as well as the instructions, rules or regulations of their application not only did not include a solution for saving documents related to organizations and institutions to which they refer, but not even included any reference to the archives (Mera 2001, cited by Porumbăcean, s.a., p. 64). The only exception in the above mentioned period is the Accounting Law (Law, 1991b), which refers to categories of documents to be handed over by autonomous administrations, commercial companies, associations and the other legal entities or individuals who have the quality of a merchant/tradesman at the State Archives in the event of inactivity.

Following the heritage privatization process, a significant abount of archives were destroyed or submitted to the authorized economic operators authorized to provide archival activity. Once the judicial status of the property was changed - including the archives - for several former communist and state companies which become private-owned companies, the consequences for these archives were negative. Some have been destroyed, for others it is difficult to identify the present owner in order to be able to prove the rights of former employees. In these circumstances, the archivists have to work at an inter-institutional level and find out where such an archive could be, given the fact that the owners could take them to any storage location within the country.

The most affected ones were those who had to prove they fulfilled the conditions imposed by the social insurance contribution. The destruction of archives had affected a large number of individuals either because they could not prove their contribution to the social insurance in the limits imposed by

\footnotetext{
5. Annex B of the Treaty of Craiova between Romania and Bulgaria, representing the agreement of the two parties concering the arrangements for evacuation and transfer of land, provided at no. 2 that "the archives of municipalities and counties, as well as the archives of the courts and of other state public Authorities existing in the territory transferred to Bulgaria, will be delivered to the Bulgarian authorities. Also they will be delivered the land plans that are submitted to the transferred territory. Regarding the cadastral plans and registers and other documents filed at Bucharest, the Bulgarian Government will be provided with certified copies".
}

6.The law was completed in 2005 by another law (Law 2005). 
law, or were not able to benefit from certain additional amounts granted subsequently; in the latter case it is about the impossibility of proving that they had worked in special/difficult conditions.

\section{Conclusions}

Each of the evoked situations have led to citizens approaches addressed and submitted to the institution of National Archives or to the creators institutions in order to identify documents attesting the rights invoked. The impact upon the National Archives was a major one, the resolution of the submitted requestes being achieved through a tremenduos human effort, particularly in terms of engaging in this activity more than $50 \%$ of staff, sometimes to the detriment of other archival activities (N.A.R, 2015). However, this reality illustrated with predilection the legal and probative value of documents, a significant component in the use of archives.

\section{References}

Badea, G., Badea A.C. (2015). From Cadastral Background of Romania to the Present. In From the Wisdom of the Ages to the Challenges of the Modern World. FIG Working Week 2015, Sofia, Bulgaria, 17-21 May 2015. Available at http://www.fig.net/resources/proceedings/fig_proceedings/fig2015/papers/ts05c/TS05C_badea_ badea_7512.pdf (accesed on 05.03.2016).

Borneman, J. (1997). Settling Accounts: Violence, Justice and Accountability in Postsocialist Europe. Princeton University Press.

Decree, 1949 - Decret no 83 of $2^{\text {nd }}$ March 1949 for certain provisions of the law no. 187 of 1945. In Buletinul Oficial, no 1/2nd March 1949.

Decree, 1950 - Decret no. 92 of $19^{\text {th }}$ April 1950 for the nationalization of property. In Buletinul Oficial, no. 36 of 20 April 1950.

Iordachi \& Dobrincu (2009). Transforming Peasants, Property and Power. The Collectivization of Agriculture in Romania, 1949-1962. Ed. C. Iordachi, D. Dobrincu. CEU Press, pp. 531.

Law, 1948 - Law no. 119 from $11^{\text {th }}$ June 1948 for the nationalization of industrial enterprises, banking, insurance, mining and transport. In Buletinul Oficial, no. 133 bis of 11 June 1948.

Law, 1991a - Land Laq no. 18 from $19^{\text {th }}$ February 1991. Republished in Monitorul Oficial, no. 1 din 5 January 1998.

Law, $1991 b$ - Accounting Law no. 82 from 24 $4^{\text {th }}$ December 1991. In Monitorul Oficial, no. 265 din 27 decembrie 1991.

Law, 1998 - Law no. 9 (r2) from $8^{\text {th }}$ January 1998 concerning the compensation to Romanian citizens for the assets passed into state ownership after applying Bulgarian Treaty between Romania and Bulgaria, signed at Craiova on September 7, 1940. Republished in Monitorul Oficial, no 956 din 28 noiembrie 2006.

Law, 2003 -Law no. 290 from $27^{\text {th }}$ June 2003 concerning the granting of compensations to Romanian citizens for their property seized, retained or remained in Bessarabia, Northern Bucovina and Herta, following the state of war and the application of the Peace Treaty between Romania and the Allied Powers, signed in Paris on February 10, 1947. In Monitorul Oficial no.505 din 14 iulie 2003.

Law, 2005 - Law no. 97 from $14^{\text {th }}$ April 2005 for the compensation for Romanian citizens who have benefited from the provisions of Law no. 9/1998 on granting compensations to Romanian citizens for the assets passed into state ownership after applying Bulgarian Treaty between Romania and Bulgaria, signed at Craiova on September 7, 1940. In Monitorul Oficial, no.325 from $18^{\text {th }}$ April 2005.

Mera L. (2001). Îndreptar arhivistic pentru personalul care creează, păstrează şi foloseşte documente, Cluj-Napoca, pp. 315-319.

National Archives of Romania (2015). Report on assessment of the achievement of specific objectives and the National Archives in 2015, pp. 1-37. Available at http://www.arhivelenationale.ro/images/custom/file/Raport\%20 ANR\%202015.pdf (accessed on 05.03.2016).

Porumbăcen, s.a. - Porumbăcean, C. Arhivele Naționale şi economia de piață, pp. 63-71.

Stan, L. (2006). The Roof over Our Heads: Property Restitution in Romania. Journal of Communist Studies and Transition Politics, Vol. 22, No. 2, June 2006, pp. 180-205.

Țineghe, C. (2012). Arhivele Statului din Chişinău şi Cernăuți între evacuarea în România (1944) şi restituirea către URSS. In Dobrincu D. (ed.), Archiva Moldaviae, IV, pp. 293-319. 
Istoricul retrocedărilor: De la naționalizarea din ,48, la listarea pe Bursă a Fondului Proprietatea (2013). Online Romanian Television News. Available at http://stiri.tvr.ro/istoricul-retrocedarilor-de-la-nationalizarea-din-48la-listarea-pe-bursa-a-fondului-Proprietatea_28502.html (accessed on 05.03.2016).

\section{SUMMARY}

The paper covers the way in which the institution of the National Archives was confronted with and tackled citizens' necessities to prove or redeem their rights after the political regime changed in 1989. A first direction envisages the land legislation, which had a major impact on the National Archives`activity. In compliance with the duties incumbent by law, it had to issue, in an accelerated pace, documents with an authentic value to prove the genuine property rights. Therefore, two situations are to be considered:

- redemption of property right for citizens whose real estates and land were abusively confiscated by the communist regime;

- property equivalence, according to the compensation or indemnification legislation, when the Romanian citizens from the historical regions of Bessarabia, Bucovina or Cadrilater (en. Quadrilateral), during the World War II, were forced to abandon their belongings and retreat in Romania.

By analysing the above-mentioned situations differences are stressed at level of the archives of the Romanian historical regions. In Transylvania and in Bucovina existed, at the end of nineteenth century, land book archive which facilitates the restoration of property rights, while Moldavia and Wallachia lacked the typical property documents, and thus the effort for the redemption of related rights was an immense one. In the latter circumstances, information had to be identified in various archives owned not only by the National Archives, but also by other public institutions and corroborated. A second direction is based on the National Archives ' control duties (according to the National Archives law) upon archives creators and owners institutions by inspecting the way in which they issue documents attesting the rights of citizens. Once the judicial status of the property was changed - including the archives - for several former communist and state companies which become privateowned companies, the consequences for these archives were negative. Some have been destroyed, for others it is difficult to identify the present owner in order to be able to prove the rights of former employees. In these circumstances, the archivists have to work at an inter-institutional level and find out where such an archive could be, given the fact that the owners could take them to any storage location within the country. All these developments have made the National Archives a very active institution with a major role in terms of proof of the claimed rights by citizens.

Typology: 1.02 Review Article

Submitting date: 23.01.2016

Acceptance date: 20.02.2016 
